\title{
Niezwykły przypadek wczesnego Mocka i klasyków
}

\section{Gerson Schade}

Eberhard Mock jest postacią fikcyjną. Marek Krajewski wymyślił go i uczynił głównym bohaterem serii kryminałów, które zaczął publikować na początku tego stulecia. Książki odniosły ogromny sukces i zostały przetłumaczone na wiele języków. Ich akcja toczy się głównie we Wrocławiu, a sześć powieści przetłumaczonych na niemiecki rozgrywa się w okresie między 1919 a 1945 rokiem. W artykule staram się zobrazować wczesne lata Eberharda Mocka, tzn. lata przed dojściem nazistów do władzy.

Przeanalizuję dokładnie trzy powieści ${ }^{1}$. Jeśli brać pod uwagę chronologię, dotyczą one pierwszych spraw w karierze Mocka. Literatura klasyczna odgrywa w nich dużą rolę ${ }^{2}$ ale w bardzo specyficzny sposób. Można wyróżnić trzy poziomy: poza nawiązaniami do starożytności w ogóle oraz szczegółowymi nawiązaniami do literatury antycznej da się zaobserwować, jak literatura klasyczna bezpośrednio i stale łączy się z pracą Mocka jako oficera policji. Ponieważ jednak Krajewski zwykle decydował się na opowiadanie historii „ze środka”, nie rozróżniając wyraźnie „głosu” narratora i umysłowej percepcji głównego bohatera, niekiedy trudno stwierdzić, kto co myśli. Można zakładać, że ta praktyka literacka jest zamierzona, a nie przypadkowa.

\footnotetext{
${ }^{1}$ Powieści Krajewskiego cytuję według ich niemieckich przekładów. Pierwsza to Gespenster in Breslau (Widma w mieście Breslau, 2005), druga to Pest in Breslau (Dżuma w Breslau, 2007), a trzecia to Der Kalenderblattmörder (Koniec świata w Breslau, 2003). Książki zostały przetłumaczone przez Paulinę Schulz, a niemiecki wydawca zaopatrzył okładki porządnie wydanych edycji kieszonkowych we wspaniałe ilustracje. Jestem bardzo wdzięczny moim polskim tłumaczom, którzy uważnie porównali mój artykuł z polskimi oryginałami powieści Krajewskiego i pomogli doprecyzować wywód. [W niniejszym przekładzie posługujemy się oryginalnymi wydaniami polskimi: Widma w mieście Breslau (W.A.B., Warszawa 2005), Dżuma w Breslau (W.A.B., Warszawa 2007), Koniec świata $w$ Breslau (W.A.B., Warszawa 2005) - przyp. tłum.]

${ }^{2}$ Mimo swojej ważności, literatura klasyczna i jej wpływ na Mocka nie zostały obszernie przebadane. Dość niedawno zajął się tym tematem K. Zieliński w artykule The ancient quotations in Marek Krajewski's detective novels, [w:] Antiquity in Popular Literature and Culture, red. K. Dominas, E. Wesołowska, B. Trocha, Newcastle 2016, s. 51-64. Autor uważa książki Krajewskiego za dowód, że istniała kiedyś „kultura cytowania”, do której literatura klasyczna należała w o wiele większym stopniu niż obecnie. Być może jest to trafna uwaga, ponieważ literatura klasyczna miała większe znaczenie dla kultury europejskiej w ogóle, przynajmniej do I wojny światowej. W odniesieniu do naszego konkretnego przypadku byłoby to jednak rozumowanie oparte na błędnym kole, ponieważ miesza literacką rzeczywistość stworzoną przez Krajewskiego z prawdziwymi realiami. Innymi słowy, nie można zakładać, że fikcyjni policjanci z Breslau (i ich żargon) „dowodzą” czegokolwiek poza tym, czego chciał Krajewski (każąc im mówić takim żargonem). A w przypadku Mocka nie chodzi tylko o popisywanie się.
} 


\section{Uwaga wstępna}

Paradoksalnie okazuje się, że Mock właściwie niewiele wyciągnął z edukacji klasycznej. Kiedyś, na wczesnym etapie życia, zakochał się w literaturze klasycznej. Bywa jednak, że nieodwzajemniona miłość przeradza się w nienawiść - niekoniecznie w stosunku do obiektu, którego kiedyś się pożądało, a którym teraz się gardzi, gdyż nie był lub już nie jest dostępny. Miłość taka może się również gwałtownie przerodzić w nienawiść do samego siebie. Być może taki mechanizm zachodzi, gdy ktoś uważa, że jest winien unieszczęśliwiania innych. Do pewnego stopnia Mock współdzieli tę narrację - nie wiedząc o tym, nie czyniąc do tego aluzji i nie czerpiąc z tego zysków - z Homeryckim Achillesem³ ${ }^{3}$ Jednak tylko do pewnego stopnia, ponieważ losy Mocka przypominają również niezwykły przypadek doktora Jekylla i pana Hyde’a oraz uzależnionego od narkotyków erudyty Sherlocka Holmesa. Jak to ma miejsce w przypadku podobnie wielopoziomowych tekstów, w jednej chwili możemy zatem zwrócić się ku zupełnie nowym horyzontom. Na początek pozostańmy przy klasyce. Jak się okaże, ci, którzy kochają zbrodnię, kochają też kulturę klasyczną ${ }^{4}$.

I.

Po raz pierwszy spotykamy Kriminalassistenta Mocka w 1919 roku. Ma wtedy trzydzieści parę lat. Pewnego poranka dowiaduje się o okrutnym morderstwie czterech młodych mężczyzn. Fakt, że rozwiązły Mock ma potężnego kaca, nie bardzo mu pomaga. Spotyka się z kolegami z pracy, wśród których pojawia się medyk sekcyjny, nazywany "Charonem” (Widma, s. 8) i w taki właśnie sposób zaczynają się nawiązania do kultury klasycznej. Przewoźnik zmarłych, barkarz zwłok, psychopompos, który przekracza jezioro Acheron w swojej dwuwiosłowej łodzi, znany z Alcestis ${ }^{5}$ Eurypidesa, rezyduje teraz w Breslau, w biurze, które rzadko opuszcza: sklerotyczny, odrobinę ekscentryczny i cierpiący na emocjonalne zatwardzenie ekspert od krojenia zwłok. Oczywiście w pewien sposób przypomina postać, która zabiera dusze zmarłych do Hadesu. To jednak kontrast nadaje ton i dzieje się tak również później.

Mock jest na przykład prześmiewczo nazywany „biczem bożym”, jakby był Attylą, znanym jako „flagello di Dio”. Jednak w przeciwieństwie do króla Hunów, Mock nie wzbudza strachu połowy Europy - jest po prostu „pogromcą obojętnych prostytutek i wenerycznych alfonsów” (Widma, s. 42). Kobietę, która wcześnie rano wyprowadza psa, można zaś zobaczyć w „bladoróżowym blasku bogini Eos" (Widma, s. 92). To rozwlekłe sformułowanie sprawia, że poranna wyprawa Mocka i jego myrmidona Smolorza wydaje się niemal homerycka. Oczywiście jest to niezgrabna parafraza tak zwanego epitetu Homeryckiego, „różanopalca Jutrzenka”. Również tutaj brzmi to nieco parodystycznie. Mock rzeczywiście często uwydatnia kontrast między pompatycznym językiem a (w najlepszym razie) trywialnym znaczeniem. W miejscu,

\footnotetext{
${ }^{3}$ Wspomina o tym Zieliński The ancient quotations..., s. 59, ale nie rozwija tego wątku.

${ }^{4} \mathrm{Na}$ podobnej zasadzie osoby, które uwielbiają powieści kryminalne, deklarują upodobanie do tragedii klasycznych i klasycznej poezji, jak stwierdził Patrick Raynal, redaktor Série Noir wydawnictwa Gallimard. Napisał on krótki wstęp do reinterpretacji Króla Edypa Sofoklesa: CEdipe roi, Paris 1994, s. 5 (skrócony w drugim wydaniu książki, Paris 2017, s. 7). Lamaison, nauczyciel języków klasycznych, przekształcił znaną tragedię Sofoklesa w thriller. Najnowszemu, drugiemu wydaniu książki towarzyszy przekład sztuki dokonany przez Lamaisona.

${ }^{5}$ Por. T. Gantz, Early Greek Myth: A Guide to Literary and Artistic Sources, Baltimore 1993, s. 125.
} 
w którym mieszka, nie ma szans na regularną kąpiel, co wyraża stwierdzeniem, że nie może codziennie składać danin Hygiei, czyli personifikacji zdrowia (Widma, s. 76) ${ }^{6}$.

Mock nie jest jedynym bohaterem, który bez trudu odwołuje się do kultury klasycznej. Pojawia się na przykład policyjny informator, który nauczył się na pamięć wszystkich łacińskich sentencji z podręcznika, bo była to jedyna książka, jaką miał pod ręką w czasie długiej morskiej podróży (Wid$m a$, s. 41) - to prawdopodobnie najniższy poziom jakiejkolwiek edukacji. Jest również Mühlhaus, nowo mianowany przełożony Mocka, który chce „zabawić się z nim w Sokratesa”, co ma pomóc Mockowi w samodzielnym znalezieniu rozwiązania. Ten jednak odmawia, otwarcie mówiąc, że nie ma czasu (Widma, s. 102). Ostatecznie przełożony ustępuje, stwierdzając, że Mock nie będzie Alkibiadesem. Co więcej, Mock lakonicznie dodaje, że Alkibiades kiepsko skończył (Widma, s. 103)7. Cała scena to nie tylko aluzja do tak zwanej metody „majeutycznej” Sokratesa, za pośrednictwem której sprawiał, że ludzie znajdowali popełnione przez siebie błędy logiczne ${ }^{8}$, ale również do słynnych anegdot łączących nauczyciela Platona (i wielu innych) z niesfornym uczniem Alkibiadesem, chłopcem z klasy wyższej, o dobrych koneksjach i niesprecyzowanych gustach. O tej relacji słyszymy wiele, a jeszcze więcej możemy się domyślić, czytając Ucztę Platona. Tekst opisuje pijatykę, na którą Alkibiades się spóźnia. W końcowej części Uczty wyznaje, że usiłował uwieść Sokratesa?

Metoda przesłuchiwania, jaką stosuje Mock, jest o wiele mniej wyrafinowana. Przesłuchując swojego przyjaciela z wojska, który okazuje się seryjnym mordercą, Mock wsadza go do basenu. Przesłuchiwany bardzo boi się zwłok, dlatego Mock pozwala, by w wodzie pływały dwa ciała (Widma, s. 288 i n.). Ostatecznie podejrzany popełnia samobójstwo. Bohater ten jest wcieleniem zła i doskonale zna teksty klasyczne. Taki zabieg może sugerować, że klasyka nie jest tu postrzegana jako coś, co z definicji sprawia, że stajemy się lepszymi ludźmi. Tę obserwację nasuwa już nastrój Mocka, wytrąconego z równowagi przez codzienne doświadczenia albo przez wcześniejszą traumę.

Perwersyjny manipulator, seryjny morderca nie tylko zaszlachtował czterech młodych mężczyzn z początku książki, ale zabił również swoją własną córkę oraz ojca Mocka. Jest niezwykle dobrze oczytany i lubi klasykę - prowadzi rodzaj pamiętnika, notatnik, który zawiera protokoły ze spotkań tajnego bractwa. W tych zapiskach wspomina na przykład swoje tłuma-

\footnotetext{
${ }^{6}$ Do obniżenia tonu dochodzi, gdy prostytutki przyłapane przez Mocka i jego kolegów in flagranti zostają nazwane „córami Koryntu” (Dżuma, s. 125) czy „kapłankami Wenery” (Koniec świata, s. 160). Poza tym główny bohater w czasie walki z dziwką w heroikomiczny sposób gwałtownie obraca się „jak starożytny dyskobol” (Dżuma, s. 131). Obraz ten przywodzi na myśl słynną grecką rzeźbę Dyskobol Myrona (która znajduje się teraz w Muzeach Watykańskich) albo Discobolo Lancelotti (z Palazzo Massimo alle Terme w Rzymie).

${ }^{7}$ Mock dość mocno się wścieka. Ledwo nad sobą panuje. Jak to zwykle bywa, pamięta tekst. Tym razem „nagle” w jego głowie pojawia się przymiotnik ze zdania Liwiusza, impotens, tj. „bezsilny, nie panujący nad samym sobą” (Widma, s. 102). Rzeczywiście Liwiusz używa sformułowań, które łączą słowo impotens ze słowami rabies albo ira, które po łacinie oznaczają „wściekłość” albo „gniew” (por. np. 29. 9. 6.): „dopiero to wpadli od razu (sic!) $\mathrm{w}$ tym większą wściekłość” - in multo impotentiorum subito rabiem accensi (por. przyp. 15).

${ }^{8}$ Kolejny wysoko postawiony urzędnik, dyrektor archiwum i/czy biblioteki, nie tylko zna „metodę majeutyczną” ale również ją lubi. Dzięki temu Mock wie, czego się spodziewać (Koniec świata, s. 271). Grecki wyraz oznacza dosłownie „położniczy” i odnosi się do działań akuszerki. Sformułowania tego używa się metaforycznie w odwołaniu do Sokratejskiego sposobu dyskutowania o problemach, często prezentowanego we wczesnych dialogach Platona, tj. udzielania pomocy w wydawaniu na świat idei i prawd znajdujących się w umyśle ucznia, za pośrednictwem serii trafnych pytań.

${ }^{9}$ Alkibiades pojawia się również w innych dziełach z tamtego czasu, na przykład w Historii wojny peloponeskiej Tukidydesa (począwszy od 5 księgi). Plutarch, grecki uczony żyjący w Rzymie w pierwszym wieku i na początku drugiego wieku naszej ery, zebrał anegdoty na temat jego biografii. Alkibiades pozostaje oczywiście postacią wielce dyskusyjną, por. np. D. Gribble, Alcibiades and Athens: A Study in Literary Presentation, Oxford 1999.
} 
czenie z łaciny (Widma, s. 57 i n.). Co więcej, pamięta, że już w szkole średniej czytał w tym języku (s. 70-72) i stwierdza, że była to „nieludzko doskonała gimnastyka mózgu”. W zapiskach cytuje też własny przekład, określając go jako toporny (s. 70). Oczywiście zachowuje się jak szaleniec, kiedy używa łacińskich słów, zamierzając zabić prostytutkę (s. 159). Rozmyśla również nad eryniami, które odgrywają dużą rolę w Orestei Ajschylosa (s. 220-2, 227-8 i 2346). Przy okazji ostatnich takich rozważań (s. 253) ujawnia się jako kronikarz tajnego bractwa.

Na samym końcu zabójca stwierdza, że koszmary Mocka to jego erynie (s. 288 i 290). Wcześniej, kiedy był już podejrzewany, ale jeszcze nie został ujawniony, zaproponował Mockowi hipnozę jako środek do odkrycia prawdziwego ja. Cytował po grecku antyczną wyrocznię, "gnothi seauton” (s. 271), namawiając Mocka, by „poznał samego siebie”, tj. „wypracował sąd o sobie”. Kartka papieru, na której napisane jest "gnothi seauton” zostaje odkryta później i dowodzi, że to właśnie ten bohater jest mordercą (s. 287). Nie trzeba wspominać, że sekretny zakon czy, jak je nazywano, Bractwo, czciło antycznych bogów greckich (s. 266). Seryjny zabójca, który był jego kronikarzem, z wysiłkiem czytał Hipokratesa po grecku (Widma, s. 173). Tym samym klasyczna edukacja zostaje wykorzystana, by przedstawić go jako postać wysoce perwersyjną, ponieważ Hipokrates pisał swoje traktaty medyczne, by chronić życie, a nie je niszczyć.

Mocka rzeczywiście nawiedzają erynie (s. 264) ${ }^{10}$, lecz są one całkowicie różne od tych, które ścigają Orestesa u Ajschylosa. Raz jeszcze, pochodzą one z niższego porządku, tak jak Mock, „proletariusz”, ale są silnie związane z kulturą klasyczną, jakiej uczy się w szkole ${ }^{11}$. Na wpół śpiący i kompletnie pijany Mock stara się przypomnieć sobie pierwsze dwadzieścia wersów Eneidy Wergiliusza (s. 271). Kiedy mu się to nie udaje, czuje się okropnie winny i w sennym koszmarze przeprasza swojego ówczesnego nauczyciela łaciny, obiecując mu, że na następny dzień nauczy się pierwszych pięćdziesięciu wierszy (s. 272) ${ }^{12}$. A krótko przed śmiercią przyjaciela, który okazał się jego wieloletnim najgorszym wrogiem, Mock przypomina sobie wykłady z językoznawstwa porównawczego (s. 289). We wspomnieniu słyszy głos profesora, który miał szansę wszystko wyjaśnić (albo i nie miał, nie dowiemy się). Intensywność, którą odczuwa Mock, może być skutkiem faktu, że czuje się przez niego (i ludzi w jego rodzaju) zdradzony. Być może to właśnie on zdradził Mocka jako pierwszy i dlatego Mock przypomina go sobie za każdym razem, kiedy znowu zostaje zdradzony, niezależnie przez kogo i w jakich okolicznościach. To ustanawiałoby „scenę pierwotną”, którą Mock ma wiecznie powtarzać, tj. źródło jego gniewu, który dzieli z Achillesem. Istnieją silne przesłanki, by dostrzec ich wspólne cechy.

Jeśli przyjmiemy tę perspektywę, asystent Mocka, Smolorz, staje się myrmidonem w dwojakim sensie. Metaforycznie: nie tylko spełnia każde polecenie bez żadnych wątpliwości, ponieważ

\footnotetext{
${ }^{10}$ Ścigają go jeszcze bardziej intensywnie w Końcu świata w Breslau (s. 169 i 257). Mock ma obsesję nie tylko na punkcie erynii, ale także na punkcie „rudowłosej” kobiety. Bez trudu tłumaczy to słowo na antyczną grekę jako pyrrhokomai (Widma, s. 192). Mock omawia też znaczenie słowa „hetera” z prostytutką, która posługuje się tym wyrazem (Widma, s. 195 i n.). Później w tej samej rozmowie Mock wspomina Lisy heter Alkifrona (Widma, s . 197). Podobna oprawa pojawia się raz jeszcze w dalszej części książki (s. 217-218). W innej scenie, obserwując willę i słysząc głos kobiety, Mock porównuje ją do syreny. Przypomina sobie siebie w czasach szkolnych, kiedy recytował Odyseje, w której śpiewają syreny (Widma, s. 251).

${ }^{11}$ Pół żartem, pół serio jeden z przełożonych sugeruje, że gdyby Mock miał herb, powinien umieścić na nim łacińskie słowo oznaczające karę, poena (Dżuma, s. 227).

${ }^{12}$ Mock uczęszczał na prowadzone przez niego nadobowiązkowe kółko klasyczne, gdzie omawiali Katullusa i Safonę (Widma, s. 200). Nic dziwnego, że umysł Mocka nazywany jest „filologicznym” (Widma, s. 254).
} 
dla niego słowa Mocka to suprema lex, najwyższe prawo, tj. wyższe niż wszystkie inne (Dżuma, s. 16 i 9) - tak właśnie, jak powinien robić myrmidon. Całkiem dosłownie, Smolorz jest jednym z ludzi Mocka, tak jak u Homera Myrmidonowie byli ludźmi Achillesa. A Mock przypomina Achillesa - jest gniewny jak on i jego również napędza gniew. W chwilach zaniepokojenia Mock próbuje się uspokoić, recytując bezgłośnie łacińską poezję (Widma, s. 137, 170 i 251). Od czasu do czasu, kiedy to robi, słyszy głos swojego nauczyciela łaciny (Widma, s. 153-154).

$\|$.

Owa analogia staje się widoczniejsza podczas naszego drugiego spotkania z Mockiem, jednakże podobieństwo do Achillesa zostało zarysowane wcześniej. W pewnym momencie najlepszy przyjaciel Mocka, który okazuje się zabójcą, porównał ich przyjaźń do tej, która łączyła Achillesa i Patroklesa (Widma, s. 82 i n.). Był wówczas kompletnie pijany, a wzmianka nie została rozwinięta.

W roku 1923 Mock ma około czterdziestu lat i został mianowany na Hauptwachtmeistra. Kryty przez przełożonych, bohatersko zareagował na owo zdobycie kolejnego szczebla kariery rokiem ciężkiego pijaństwa w więziennej celi, której pilnował przyjaciel (Dżuma, s. 35 i n.).

Od samego początku Mock przejawia znajomość literatury klasycznej i to właśnie w tym kontekście objawia się jego achillesowski temperament. Podczas pobytu w burdelu Mock posługuje się dość elementarnymi zwrotami łacińskimi, aby opisać swoje upodobania seksualne ${ }^{13}$. Zapytany przez prostytutkę o powód, odpowiada, że starożytni Rzymianie byli ekspertami w ars futuendi (Dżuma, s. 31) ${ }^{14}$. Jest to dość zarozumiałe zachowanie, jako że prostytutka z trudem może zrozumieć, co miał na myśli. Mock rozwija stwierdzenie, oświadczając, zapewne słusznie, że współczesne wyrażenia są albo czysto anatomiczne, albo zwyczajnie wulgarne. Choć brzmi to odrobinę zbyt dydaktycznie, może być uznane za element ironii narracyjnej. Koniec końców, Mock jest Niemcem i z tego powodu staje się obiektem drwin. Widzimy, że ten wzorzec zachowań się powtarza.

Achillesowa dusza Mocka niespodziewanie daje o sobie znać kilka stron później, w dalszym ciągu w kontekście posługiwania się przez niego łaciną w sytuacjach codziennych. Wszystko dzieje się - jak można się tego spodziewać po typie spod ciemnej gwiazdy, jakim jest Mock w trakcie absurdalnej, dość Chaplinowskiej sceny. Mock wchodzi do sklepu, ponieważ obawia się, że spadną mu spodnie. Prosząc o kawałek sznurka, wykrzykuje łaciński przysłówek cito, „szybko” (Dżuma, s. 38). Sprzedawca stwierdza w odpowiedzi, że takimi słowami może posługiwać się w aptece albo w pralni, ale nie u niego, co rozsierdza Mocka ${ }^{15}$.

Napotykamy znajomy już wzorzec. Za każdym razem, gdy Mock chce się uspokoić, stara się przywołać łacińskie lub greckie wyimki, których uczył się na pamięć w szkole. Tym razem jednak jeden wyraz mu umyka, nie jest w stanie dokładnie przypomnieć sobie tekstu i wpada w silny gniew (Dżuma, s. 63). Nic dziwnego, że przełożeni postrzegają go jako emocjonalnie

\footnotetext{
${ }^{13} \mathrm{~W}$ innej scenie, dokonując oględzin ciał, Mock ponownie posługuje się wyrażeniami łacińskimi, opisując upodobania erotyczne (Dżuma, s. 43).

${ }^{14} \mathrm{~W}$ innym tekście czytamy o porządniejszej „ars amandi” (Koniec świata w Breslau, s. 95).

${ }^{15}$ Albo jak ujmuje to Liwiusz (por. np. 29. 9. 9), impotens irae - na określenie osoby, która „z powodu gniewu wyszła z siebie" (por. przyp. 7)
} 
niestabilnego (Dżuma, s. 52) ${ }^{16}$ - podobnie Agamemnon mógł oceniać Achillesa. Na dodatek pojawia się kolejne podobieństwo: przełożony Mocka, Mühlhaus, który naśladuje patos szkolnego nauczyciela imitującego Cycerona (Dżuma, s. 50 i n.), jawi się jako potwornie cyniczny i pompatyczny idiota - tak samo jak Agamemnon przedstawiony przez Homera. Tak się składa, że nie jest równie wykształcony co Mock, podobnie jak i Agamemnon nie jest równie biegły co Achilles: Mühlhaus nie wie, co znaczy słowo „trybady”, którym Mock posługuje się zamiast słowem „lesbijki” (Dżuma, s. 44).

Zostaje rozwinięta również inna kwestia, która pojawia się już wcześniej. Mock za młodu marzył o karierze akademickiej; dowiadujemy się, że pisał artykuły po łacinie (Widma, s. 230). Teraz spotykamy go w niedzielny poranek, gdy siedzi samotny w swym biurze, spoglądając na zdjęcie zmarłego ojca, szewca (Dżuma, 58 i n.) i wyobraża sobie, że ten zbeształby go za porzucenie studiów. W szkole Mock wygłosił nawet przemówienie po łacinie, a nauczyciel pogratulował wówczas ojcu sukcesu syna. A jednak, obiecujący młody Mock poniósł porażkę. Rzecz jasna, biedował (Dżuma, s. 195), ale choć pragnął podziwu, jakim cieszył się wówczas „profesor Morawjetz”, nie był w stanie wziąć się do roboty ${ }^{17}$. Jeśli weźmiemy pod uwagę tę historię, Mock przypomina degenerata - którym prawdopodobnie jest, albo przynajmniej coraz bardziej się staje.

W ostatecznym rozrachunku fabuła drugiej książki przypomina pierwszą sprawę Mocka: ponownie musi zmierzyć się z tajnym bractwem i raz jeszcze „oni” okazują się wykształceni w klasycznym sensie tego słowa. Kultura klasyczna znów okazuje się atrakcyjna dla rozmiłowanych w zbrodni. Dla przykładu: gdy policyjny agent chce nawiązać $\mathrm{z}$ „nimi” kontakt, ma umieścić ogłoszenie w dzienniku. Jego zadaniem jest precyzyjne posłużenie się błędną formułą łacińską requiescant in pacem (Dżuma, s. 104 i 109). Neofita wie, że nazwa bractwa, „mizantropi”, jest słowem z greki, i że nie ma nic wspólnego ze sztuką Moliera (Dżuma, s. 118). A zatem, ci, co są wykształceni, są źli, albo raczej, ci, co są źli, są wykształceni ${ }^{18}$. Co niezbyt zaskakujące, stanowią również „ostoję społeczeństwa” (Dżuma, s. 119).

Wraz z rozwojem narracji, achillesowe cechy Mocka coraz silniej determinują akcję, wysuwają się na plan pierwszy. Dla przykładu, Mock wpada w taki gniew, że jego zwyczajowe metody uspokojenia się zawodzą. Ani recytowanie Wergiliusza o Tytyrusie (z początku Bukolik, napisanych pomiędzy 42 a 37 r. p.n.e.), ani Horacego o górze Sorakte (jednej z jego dość słynnych Ód, z pierwszego zbioru, opublikowanego w 23 r. p.n.e.) - wyimków, których Mock nauczył się na pamięć w gimnazjum w rodzinnym Waldenburgu - nie jest w stanie już go uspokoić (Dżuma, s. 122).

Oba teksty są postrzegane nie tylko jako autobiograficzne rozważania Wergiliusza i Homera nad ich życiową sytuacją. Oba są również silnie zadłużone we wcześniejszej poezji greckiej: w przypadku

\footnotetext{
${ }^{16}$ Nagłe zmiany nastroju nie umykają Mockowi, który określa rozgniewane kobiety mianem „Harpii” (Dżuma, s. 53 i 130). Harpie są skrzydlatymi stworzeniami, przedstawicielkami Furii i karą zesłaną od bogów. Są znane od czasów Odysei, w której ich imię zostaje użyte na personifikację wirów wodnych i huraganów.

${ }^{17}$ Przebywanie na nizinach społecznych i łacina jeszcze zabawniej spotykają się, gdy Mock kupuje kiełbasę w sklepie rzeźnickim „Carnis”. Na dworcu widzi ponownie nazwę „Carnis”, tym razem nadrukowaną na papierze używanym do pakowania kanapek z szynką (Dżuma, s. 72 i 184).

${ }^{18}$ Gdy cytują literaturę klasyczną, wyróżniają się z tłumu. Zdecydowanie nie są po prostu osobliwi, albo troszkę dziwaczni, albo odrobinę ekscentryczni, albo raczej stuknięci, niczym jeden z kolegów Mocka. Jest on przekonującą karykaturą wyższego urzędnika administracji państwowej - tchórz i służbista, pozbawiony jakiejkolwiek inicjatywy, lecz zdolny do produkcji wysoce fantazyjnych raportów, nieustannie radujący się z wyrażeń w stylu „warunek sine qua non” albo nolens volens (Dżuma, s. 80 i 82).
} 
Wergiliusza jest to Teokryt, hellenistyczny poeta z Aleksandrii początków III wieku, a dla Horacego to Alkajos, poeta epoki archaicznej żyjący na Lesbos pod koniec VII wieku. A zatem klasyczne teksty, do których pojawiają się odwołania, nie mają po prostu tylko drugiego dna. Nie jesteśmy w stanie w pełni i właściwie ich docenić, nie uwzględniając ich greckich prekursorów. Mocą implikacji oznacza to, że osobowość Mocka również ma drugie dno. Pojawia się sugestia, doprawdy wysoce prawdopodobna, iż wbrew temu, czego można by się spodziewać po policyjnym oficerze z międzywojennego Breslau, jest coś jeszcze, co określa tę postać. Na takiej samej zasadzie, jak było coś jeszcze (tj. coś greckiego i znajomość wielkiej tradycji), co określało poezję Wergiliusza i Horacego wbrew temu, czego można się spodziewać z faktu, że byli poetami augustowskimi nadzorowanymi i kierowanymi przez mecenasów. Przynajmniej tak pomyślałby filolog klasyczny.

Dodatkowo Mock, podobnie jak Achilles, poczuwa się do winy. Zadręcza się, że jego informator popełnił samobójstwo, ponieważ Mocka nie było na miejscu i nie mógł mu pomóc (Dżuma, s. 124). Achilles w bardzo podobny sposób myślał o Patroklesie. Tak samo jak Mock, Achilles, wódz Myrmidonów, czuł się winny (Iliada 18), ponieważ jeden z jego ludzi zginął podczas akcji. To silnie odróżnia go od jego odpowiednika spod Troi, księcia Hektora, który obawia się jedynie, iż zrobi złe, tj. przynoszące wstyd, wrażenie na trojańskich kobietach (Iliada 6 i 22). W ten sposób zostaje ustanowiony długowieczny stereotyp: męski Zachód i zniewieściały Wschód.

Co ciekawe, Mock ma świadomość istnienia niektórych z tych greckich modeli. W czasie przesłuchania klient prostytutki jest przykuty do wezgłowia łóżka, podczas gdy ona sama, również przykuta, leży nieprzytomna u jego boku. Mock rozpoczyna przesłuchanie od pytania, czy klient kiedykolwiek czytał Lukrecjusza, czemu ten zaprzecza (Dżuma, s. 132). W rezultacie Mock zaczyna entuzjastyczny wykład o stracie klienta, przechodząc na Homeryckie źródło tekstu Lukrecjusza i mówi dalej o Aresie i Afrodycie (nakrytych podczas cudzołóstwa i unieruchomionych przez Hefajstosa), a nie Marsie i Wenerze ${ }^{19}$. W końcu sfrustrowany Mock oznajmia podczas przesłuchania, iż od tej pory nie będzie już „uprzejmym akademikiem, który mówi o Homerze" (Dżuma, s. 136). Dobrze znamy takich nauczycieli literatury klasycznej o sadystycznych upodobaniach.

Udowodniwszy swój umięśniony profesjonalizm, Mock desperacko potrzebuje paru kufli piwa, które zostaje określone mianem „wody z rzeki zapomnienia” (Dżuma, s. 138). Wyrażenie stanowi aluzję do rzeki Lete, a jej nazwa oznacza dosłownie „stan bycia ukrytym”, stąd „zapomnienie”. To nazwa jednego z miejsc zapomnienia w dolnym świecie, czasami wyobrażanego jako rzeka, czasami jako zwykła równina. O czym konkretnie Mock chce tak pilnie zapomnieć? Nie może być to prawda o morderstwie, ponieważ jego zadaniem, jako oficera policji, jest odkryć prawdę. Prawda to po grecku a-leth-eia, tj. to, co nie może być ukryte, nie pozostaje ukryte, a wręcz przeciwnie, to, co jest oczywiste, jawnie widoczne dla każdego. Trzeba zatem wnosić, że Mock chce zapomnieć o sobie, o swoich działaniach. Ale dlaczego? Czyż może być tak, że z takich czy innych przyczyn postrzega je jako naganne, niegodne człowieka o jego wykształceniu?

${ }^{19}$ Zieliński zauważa, że Krajewski „regularnie powraca do tej sceny” K. Zieliński, The ancient quotations..., s. 55 i 60 przyp. 2). 
Wróg natomiast nie posiada podobnych etycznych skrupułów i nigdy nie śpi. Narracja, już i tak szybko prowadzona, przyspiesza. Istnieją trzy sposoby, aby dołączyć do elitarystycznego i wykształconego bractwa zabójców: wszystkie nazwane wyłącznie po łacinie (Dżuma, s. 145). Sprawę komplikuje fakt, że to Mock jawi się jako zabójca, na skutek działań własnego przełożonego, który chce, by jego podwładny dołączył do zbrodniczego stowarzyszenia. Czytamy, że gniew „targał nim dotkliwie” (Dżuma, s. 152). W rezultacie, upokorzony, skuty kajdankami, wściekły Mock jest przesłuchiwany przez swych kolegów, którym z drwiną opowiada, że retoryczne narzędzie retardacji „znał już Homer” (Dżuma, s. 157). Wkraczając do więziennej celi, Mock zostaje porwany przez bezbrzeżny gniew wymieszany z przytłaczającym smutkiem - u Homera oba uczucia zdają się siłami napędzającymi Achillesa (Dżuma, s. 168). Siedząc już spokojnie w celi, wykształcony Mock roztrząsa łacińskie nazwy karaluchów (Dżuma, s. 171) i prosi swego myrmidona, Smolorza, by przysłał mu Elegie Teognisa w greckim oryginale (Dżuma, s. 175).

Zważywszy na sytuację, jaką musi przetrzymać Mock, książka Teognisa, z której pochodzi również motto powieści, jest absolutnie nadzwyczajna. Dzieło Teognisa (w znacznej mierze napisane przez kogoś innego) może równie dobrze być zbiorem pijackich piosenek stworzonych na potrzeby męskiego sympozjonu. To doskonale pasuje do Mocka. Więcej: niektóre z najbardziej niezwykłych tekstów Teognisa są kierowane do bliskiego przyjaciela; Mock za takowym desperacko tęskni - tak jak Achilles tęsknił za Patroklesem. A teksty Teognisa (przynajmniej te, które mu przypisujemy) mają silne nachylenie arystokratyczne, co z pewnością przemawia do szlachetnego Mocka. Teognis jest, na nieszczęście i na własną niekorzyść, również niepokojąco szczery odnośnie do swych emocji, podobnie jak Mock i Achilles. Co być może najważniejsze, Teognis wierzył, a przynajmniej wyrażał wiarę w „tradycyjne zasady greckiej moralności” ${ }^{20}$ - podobnie jak Mock i Achilles. Zważywszy na wszystkie te podobieństwa, nie zaskakuje, że Mock zna na pamięć ów tekst, który można dostrzec „w świetle Selene” (Dżuma, s. 176).

Jednakże w oczach innych, klasyczne wykształcenie Mocka sprowadza się do wrażenia, że no cóż - mówi zbyt długo, zbyt obszernie okraszając wywód cytatami z łaciny i greki, rozkoszując się „łacińskimi maksymami i starożytnymi dykteryjkami” (Dżuma, s. 206 i n., i 213). Niewykształconym wykształcenie jawi się zwykle jako arogancja (albo gorzej).

Napady gniewu Mocka trwają dalej, stają się nawet jeszcze poważniejsze. Zagrażają równowadze jego umysłu, któremu, zważywszy na presję, grozi rozstrojenie i są opisywane „z wewnątrz" (Dżuma, s. 229 i n.). Podobne crescendo można zauważyć w trakcie relacji członków morderczego bractwa, które przedstawiane są jako pełne odor mortis (Dżuma, s. 231). Upadek jest doprawdy nieunikniony. Koniec końców, działalność tajnej organizacji zostaje zakończona. Aby uczcić tę chwilę, przełożony Mocka, Mühlhaus, daje mu elegancki surdut, a sam otrzymuje od niego zwykłą, prostą marynarkę - Diomedowa zamiana, jeśli można tak to określić (Dżuma, s. 247) ${ }^{21}$. Autor uszlachetnia narrację poprzez aluzję do słynnej sceny z szóstej księgi

\footnotetext{
${ }^{20}$ Cecil Bowra posługuje się tym wyrażeniem w artykule na temat Teognisa w The Oxford Classical Dictionary (Oxford 1949, s. 894).

${ }^{21}$ Zieliński nazywa to „pokazem męskiej przyjaźni” (K. Zieliński, The ancient quotations..., s. 55, przyp. 2).
} 
Iliady, w której Grek i Trojanin, Diomedes i Glaukos, wymieniają się bronią, ponieważ nagle uświadomili sobie, iż dawno temu ich rodziny zawiązały przyjacielskie stosunki, jak to często ma miejsce wśród arystokracji.

Dostrzeże to jednak niewielu, jako że nic nie zdradza aluzji ${ }^{22}$. Zauważamy tę subtelność, jedynie dzięki temu, że my, czytelnicy, wiemy, jak poważnie Mock traktował klasyków, co potwierdza jego były kolega z czasów studiów (Dżuma, s. 235), i jedynie dzięki temu, że zaczynamy dostrzegać, jak działają filologicznie wykształcone umysły. Zważywszy jednak na tę perspektywę, Mock okazuje się nie tylko głównym bohaterem powieści, ale również ich zamierzonym, głównym czytelnikiem. Byłby zachwycony tym porównaniem. Rzecz jasna nie umknęłoby jego uwadze, nawet gdyby był zalany w trupa.

Jako że klasycy są w odwrocie i - by rzecz ująć delikatnie - znaczą bardzo wiele dla bardzo niewielu, powieści o Mocku muszą jednak przemawiać do czytelników z innego powodu niż aluzje do klasycznych motywów. Czy jest może tak, że owe pozornie banalne kryminały są równie atrakcyjne co Iliada Homera z tego samego powodu? Iliada notorycznie skupia się na nieprzewidywalności działań bohatera, motywie, który staje się tym bardziej interesujący, że Achilles wyróżnia się niezwykłymi siłami, zarówno fizycznymi, jak i umysłowymi. Dokładnie tak jak Mock.

Na dodatek autor Iliady starannie wykreował wyobrażone społeczeństwo, włączając do dzieła tak fantastyczne rzeczy jak pedantycznie opisaną tarczę Achillesa, a nawet prawdziwie surrealistyczny hełm z ciosami dzika - przedmiot, który do dzisiaj można oglądać w niektórych zbiorach. To samo dotyczy autora opowieści o Mocku.

Autor Iliady stworzył słynny sztuczny język. Obok siebie pojawiają się formy pochodzące z różnych dialektów, co w zwykłych warunkach się nie zdarzało, a te same czasowniki koniugują się według różnych paradygmatów, co nie mogłoby kiedykolwiek zaistnieć, a już na pewno nie w okresie, w którym rzekomo żył Homer. Mówiąc inaczej, sztuczność Iliady nieustannie zderza się z jej realizmem - ku rozgoryczeniu filologów klasycznych. Czyż nie jest to podobne do Mocka, który posługuje się owymi staromodnymi obrazami Harpii, Syren i Furii, od dawna martwymi i pogrzebanymi? Mocka, który mówi po łacinie i myśli w grece, językach równie martwych i pogrzebanych? I czyż Mock nie żyje w sztucznym świecie dżentelmenów, którzy traktują się honorowo - tak, jak chciał tego Achilles? I czyż obaj nie są potwornie zawiedzeni swymi kompanami - pijaczynami na ciężkim kacu?

|ll.

Po raz trzeci spotykamy Mocka na przełomie 1927 i 1928 roku. To jego ostatnie pojawienie się przed dojściem nazistów do władzy. Ożenił się z piękną i młodą, wiecznie niezaspokojoną seksualnie Sophie. Ona ma 24 albo 25 lat, on określany jest jako czterdziestokilkulatek (Koniec świata, s. 13 i 36). Tym razem jednak, Kriminalrat Mock, ze Smolorzem jak zawsze przy boku, musi zmierzyć się z samotnym wilkiem, a nie, jak w poprzednich razach, konfrontować się $\mathrm{z}$ tajnym bractwem.

\footnotetext{
${ }^{22}$ Przynajmniej w niemieckim przekładzie. Polski oryginał natychmiast ujawnia kontekst homerycki, na co zwrócili mi uwagę moi polscy tłumacze.
} 
Młoda żona brutalnie przypomina Mockowi o tym, że kiedyś studiował łacinę i chciał zostać profesorem. Bratanek Erwin jeszcze pogarsza sprawę, mówiąc, że stryj Ebi opublikował kiedyś artykuł na temat Horacego po łacinie (Koniec świata, s. 15 i n.). Co więcej jego żona zdradza, że mąż po cichu czytuje w domu Horacego, korzystając ze szkolnego wydania zaopatrzonego w słowniczek, które bardzo mu odpowiada, ponieważ wiele zapomniał. Być może - rozmyśla żona - jest gejem (albo nie), skoro marzyła mu się profesura. Nie ma się co dziwić, że taka dysfunkcyjna impreza rodzinna inspiruje Mocka, by porządnie się upić ${ }^{23}$.

Jego powrót do domu zostaje rozlegle porównany do powrotu Odyseusza (Koniec świata, s. 18): wspomniane zostają Scylla, Charybda, Syrena, stary pies Argos i Itaka ${ }^{24}$. Mock trzyma w domu wydania prawie wszystkich klasycznych tekstów. Jego wydanie Galena jest dwujęzyczne, tj. po grecku i po łacinie, ponieważ pasuje do „niedoszłego filologa klasycznego” (s. 37 i 40).

Nawyk Mocka polegający na tym, że aby się uspokoić, recytuje poezję, której kiedyś nauczył się na pamięć, zostaje ponownie przywołany. Jednak tym razem po raz pierwszy dzielimy to doświadczenie całkiem intensywnie, minuta po minucie, w czasie rzeczywistym. Mock chce wyciągnąć informacje od swojego rozmówcy. Zaczyna po cichu recytować wiersz Horacego, który zamyka jego pierwszy zbiór. Horacy mówi o poezji, którą zamierza rozpowszechnić i która zabezpieczy mu pozycję, jakiej nigdy nie zniszczy czas. Rozmówca Mocka jest półgłówkiem, więc w oczekiwaniu na odpowiedź policjant ma czas na przywołanie aż pięciu wersów. Wreszcie nie może sobie przypomnieć więcej i zadaje drugiemu mężczyźnie cios. My, czytelnicy, zrozumiemy w czym rzecz tylko, jeśli znamy wiersz na pamięć albo go sprawdzimy, bo narrator cytuje dopiero szósty wers łacińskiego tekstu.

Jest on interesujący sam w sobie, ponieważ stanowi ironiczny metatekst do przesłuchania: „Nie wszystek umrę”, stwierdza Horacy. Ma przez to na myśli, że tylko jego ciało pewnego dnia umrze, ale nigdy nie umrze duch jego poezji: non omnis moriar (Koniec świata, s. $85=$ Horacy 3. 30. 6).

Na szczęście Mock przypomina sobie trochę tekstu. To pozwala mu kontynuować bezgłośną recytację i jednocześnie dotkliwie bić drugiego mężczyznę (s. 86). Dochodzi do rzeki Aufidus, która w łacińskim tekście pojawia się w wersie dziesiątym. Deklamuje uroczyście, jak przystało na poezję tego typu, a jego przeciwnik przypomina już teraz raczej kogoś umarłego niż żywego. W tej chwili Mock naprawdę wybucha i „nie recytuje już w myślach Horacego” (s. $88)^{25}$. Wydaje się, że nie jest w stanie dłużej podążać za „precyzyjną gramatyką” (s. 96), co jest konieczne, gdy prowadzi się śledztwo w sprawie morderstwa.

${ }^{23} \mathrm{~W}$ tym momencie zgadujemy, że małżeństwo nie przetrwa długo i że prawdopodobnie tak samo będzie z bratankiem. Tak właśnie się dzieje.

${ }^{24}$ Zabawne, że dalej Argos będzie się pojawiał regularnie: stał się symbolem spokojnego gospodarstwa domowego (Koniec świata, s. 18, 39, 66, 68, 843114 i 147). Kiedy nie ma psa, wszystko idzie nie tak. Jak na ironię, w domu Mocka napis „Uważaj na psa” jest wypisany po łacinie na stopniu przy wejściu (s. 83).

${ }^{25} \mathrm{~W}$ innej chwili silnego gniewu Mock recytuje odi profanum vulgus Horacego (Koniec świata, s. 261). W tym utworze poeta-kapłan każe odejść niewtajemniczonym i bezbożnym. Ten motyw pojawia się często, jak na przykład u Wergiliusza, kiedy Eneasz odwiedza zaświaty (Eneida, 6. 258 procul o, procul este, profani). Dzisiaj nadal funkcjonuje jako popularny dowcip i łatwo może stać się popularny wśród uczniów, którzy uczą się łaciny w szkole. 
W innych trudnych chwilach Mock pamięta jednak dokładnie rzeczy, które wydawały się „stałe i niezniszczalne", jak łacińskie seminaria i wiersze, których uczył się na pamięć (s. 141 i n.). Być może to ta nostalgia każe mu przemawiać jak wykładowca uniwersytecki ${ }^{26}$, ale zawsze niezbyt przekonująco i tylko kiedy jest pijany (s. 91). Wraz z tym, jak taki schemat zachowań staje się coraz częstszy, zaczynamy się zastanawiać, co mogło go wywołać. Czy to niedojrzałość schlebiającego sobie dorosłego? Czy wyniosły Mock jest autodestruktywnym „dużym chłopcem", cierpiącym z powodu ciężaru obowiązków, od których nie potrafi i nie chce się uwolnić?

Kimże on jest? Widzimy Mocka paskudnego, który chełpi się swoją łaciną (s. 175). Odrzuca jednego ze współpracowników, ponieważ ten nią nie włada (s. 221), twierdząc (słusznie), że aby przewidzieć kolejne zabójstwo, grupa policjantów musi przeczytać dokumenty w tym języku i właściwie je zrozumieć (s. 232). Widzimy Mocka opiekuńczego, który pomaga koledze z klasy swojego bratanka przetłumaczyć wiersz Katullusa, tak jak już wcześniej pomagał grupie jego kolegów, wyjaśniając „pokrętny styl” Liwiusza (s. 252) ${ }^{27}$. Ich szkolny nauczyciel to kolega Mocka z lat młodości, z czasów, kiedy obaj bali się swojego profesora (s. 253).

Punkt kulminacyjny powieści, Horacjański pomnik wybudowany na jej końcu, by tak rzec, to bezlitosny portret wykształconych zwyrodnialców. Trudno się zdecydować, kto bardziej przypomina wcielone zło - Mock czy morderca. Seryjny zabójca jest nauczycielem łaciny w gimnazjum, szanowanym „Gymnasialprofessor”. Mock torturuje go, cynicznie zwracając się do niego po łacinie. Mówi o tym, że można jednocześnie chcieć coś zrobić i nie być w stanie tego zrobić. By zilustrować, o co mu chodzi, Mock cytuje frazę z podstawowej gramatyki łacińskiej. Po sadystycznym, lecz skutecznym ćwiczeniu, które sprawia, że zatrzymany okropnie cierpi, Mock wyjawia, iż cytat pochodzi z Owidiusza: ut desint vires, tamen est laudanda voluntas (s. 280) ${ }^{28}$.

\section{Zakończenie}

Po przeczytaniu tych książek można się zastanawiać, co stałoby się z taką zagubioną duszą, gdyby nagle została zmuszona do życia w tyranii. Można dociekać, czy bohater zbuntuje się przeciwko niej, czy też będzie czerpał z niej korzyści. Wiele zwichniętych umysłów robiło wówczas błyskotliwą karierę. Być może chciałby po prostu żyć dalej tak, jak żył. W każdym razie, w otwarciu kolejnej książki ${ }^{29}$, na początku epoki nazistowskiej, spotykamy dobrze opłacanego starszego oficera policji Mocka w burdelu. Jest jeszcze bardziej zdegenerowany niż kiedykol-

\footnotetext{
${ }^{26}$ Na podobnej zasadzie Mock mówi o XIX wieku jako o „prawidziwym saeculum historicum” (Koniec świata, s. 171), nazywając dyrektora biblioteki „polihistorem, historykiem w Herodotowym znaczeniu” - co jest przestarzałą oceną, która sama należy do XIX stulecia.

${ }^{27} \mathrm{~W}$ starożytności Liwiusz słynął ze swej łaciny, odbiegającej od czasu do czasu od czystego języka, który dla rzymskich autorów był święty. Przyjaciel Horacego i Wergiliusza, Gajusz Azyniusz Pollion, żartobliwie oskarżał go o „patavinitas” - eufemizm ukuty dla niego w związku z tym, że urodził się w Padwie, tj. z dala od miejskiego wyrafinowania.

${ }^{28}$ Wers pochodzi z listu, który przebywający na wygnaniu Owidiusz wysłał do przyjaciela przebywającego w Rzymie. Owidiusz pisze w nim o sobie. Choć brakuje mu sił, mówi, że nadal jest zdeterminowany (Epistulae ex Ponto 3. 4. 79). Mock jednak używa tego cytatu w charakterze zgryźliwej uwagi na temat słabnących sił swojej ofiary. Mock mógłby zaczerpnąć od Owidiusza również rozumowanie Medei. Choć odróżnia ona, a nawet pochwala dobro, wybiera zło, mówiąc video meliora proboque, deteriora sequor (Metamorfozy, 7. 70 i n.) i podobnie czyni Mock. To zdanie nie pojawia się jednak w podstawowych podręcznikach do łaciny.

${ }^{29}$ Śmierć w Breslau została opublikowana w 2003 roku. Niemieckie tłumaczenie Doreen Daume, Tod in Breslau, pojawiło się w roku 2009.
} 
wiek wcześniej i czyta fragmenty swoich esejów na temat charakteru ludzkiego zmęczonym prostytutkom, którym płaci za słuchanie (Śmierć, s. 13 i n.) ${ }^{30}$. W tym samym momencie widzimy pijanego głupca i zepsutą do szpiku kości ostoję społeczeństwa, która zamorduje miliony.

\section{Przełożyli Krzysztof Hoffmann i Weronika Szwebs}

\footnotetext{
${ }^{30} \mathrm{Z}$ poprzedniej powieści wiemy, że Mock prywatnie pisuje charakterystyki osób, które przypominają te pisane przez Teofrasta, ucznia i następcę Arystotelesa (Koniec świata, s. 33).
} 


\title{
SEOWA KLUCZOWE:
}

\author{
recepcja poezji greckieji łacińskiej
}

\section{KRYMINAE}

\begin{abstract}
AbSTRAKT:
Od ponad dekady Marek Krajewski publikuje kryminały, w których pojawia się postać oficera policji Eberharda Mocka. Choć proletariusz Mock jest synem szewca, uczył się w gimnazjum, a nawet na uniwersytecie. Widzimy, jak w międzywojennym Wrocławiu przypomina sobie klasyczne teksty, które nadal czytuje w oryginale. Nie jest jedynym policjantem z powieści kryminalnej, który ma taki zwyczaj. Do klasycznych tekstów powraca również we współczesnej Wenecji Commissario Brunetti, bohater opowieści Donny Leon. Jednak dobry glina Brunetti, człowiek spokojny i ustatkowany, szczęśliwy mąż wykładowczyni anglistyki na Uniwersytecie Ca' Foscari, bardzo się różni od złego gliny Mocka, bohatera bardziej impulsywnego, nieustannie pobudzanego przez rudowłose prostytutki. Mock studiował kiedyś języki klasyczne i publikował artykuły naukowe po łacinie. Teraz prowadzi rozwiązłe życie, spędzając więcej czasu w burdelach niż w domu i to nie tylko z powodu obowiązków służbowych. Może to intensywne wspomnienia sprawiają, że działa w sposób tak niezrównoważony? Najczęściej Mock przypomina sobie swoją edukację klasyczną nagle, mimowolnie, tak, jakby przypominał sobie traumę. Kiedy przyjrzymy się bliżej, okazuje się, że te na pierwszy rzut oka przypadkowe cytaty stanowią komentarz do narracji, a proces ten jest zrozumiały wyłącznie dla Mocka, który upodabnia się coraz bardziej do zanurzonego w klasyce samotnika. Jako że jego siłami napędowymi są olbrzymi gniew i przytłaczający smutek, Mock odzwierciedla wielkiego bohatera Homeryckiego, Achillesa.
\end{abstract}




\section{recepcja edukacji klasycznej}

\section{Achilles}

\section{NOTA O AUTORzE:}

Gerson Schade - wykładowca filologii klasycznej na Uniwersytecie im. Adama Mickiewicza w Poznaniu. Studia klasyczne i z lingwistyki porównawczej odbył na Freie Universität w Berlinie. Poza filologią zorientowaną na tekst interesuje się recepcją tekstów klasycznych przez współczesnych autorów. Wydawnictwo Naukowe UAM wydało ostatnio dwa zbiory jego wykładów. 